\title{
Global Warming Effects on Irrigation Development and Crop Production: A World-Wide View
}

\author{
Daniele De Wrachien', Mudlagiri B. Goli² \\ ${ }^{1}$ Department of Agricultural Engineering, State University of Milano, Milano, Italy \\ ${ }^{2}$ Mississippi Valley State University, Itta Bena, USA \\ Email: daniele.dewrachien@unimi.it
}

Received 26 June 2015; accepted 28 July 2015; published 31 July 2015

Copyright (C) 2015 by authors and Scientific Research Publishing Inc.

This work is licensed under the Creative Commons Attribution International License (CC BY). http://creativecommons.org/licenses/by/4.0/

(c) (i) Open Access

\section{Abstract}

Despite the enormous advances in our ability to understand, interpret and ultimately manage the natural world, we have reached the 21 st century in awesome ignorance of what is likely to unfold in terms of both the natural changes and the human activities that affect the environment and the responses of the Earth to those stimuli. One certain fact is that the planet will be subjected to pressures hitherto unprecedented in its recent evolutionary history. The "tomorrow's world" will not simply be an inflated version of the "today's world", with more people, more energy consumption and more industry, rather it will be qualitatively different from today in at least three important respects. First, new technology will transform the relationship between man and the natural world. An example is the gradual transition from agriculture that is heavily dependent on chemicals to one that is essentially biologically intensive through the application of bio-technologies. Consequently, the release of bio-engineered organisms is likely to pose new kinds of risks if the development and use of such organisms are not carefully controlled. Second, society will be moving beyond the era of localized environmental problems. What were once local incidents of natural resource impairment shared throughout a common watershed or basin, now involve many neighboring countries. What were once acute, short-lived episodes of reversible damage now affect many generations. What were once straightforward questions of conservation versus development now reflect more complex linkages. The third major change refers to climate variations. It is nowadays widely accepted that the increasing concentration of the so-called greenhouse gases in the atmosphere is altering the Earth's radiation balance and causing the temperature to rise. This process in turn provides the context for a chain of events which leads to changes in the different components of the hydrological cycle, such as evapotranspiration rate, intensity and frequency of precipitation, river flows, soil moisture and groundwater recharge. Mankind is expected to respond to these effects by taking adaptive measures including changing patterns of land use, adopting new strategies for soil and water management and looking for non-conventional water re- 
sources (e.g. saline/brackish waters, desalinated water, and treated wastewater). All these problems will become more pronounced in the years to come, as society enters an era of increasingly complex paths towards the global economy. In this context, engineers and decision-makers need to systematically review planning principles, design criteria, operating rules, contingency plans and management policies for new infra-structures. In relation to these issues and based on available information, this report gives an overview of current and future (time horizon 2025) irrigation and food production development around the world. Moreover, the paper analyses the results of the most recent and advanced General Circulation Models for assessing the hydrological impacts of climate variability on crop requirements, water availability and the planning and design process of irrigation systems. Finally, a five-step planning and design procedure is proposed that is able to integrate, within the development process, the hydrological consequences of climate change. For researchers interested in irrigation and drainage and in crop production under changing climate conditions, references have been included, under developments in irrigation section on Page 3. Many climate action plans developed by few cities, states and various countries are cited for policy makers to follow or to make a note off. Few citations are also included in the end to educate every one of us, who are not familiar with the scientific work of our colleagues, related to global warming. The colleagues are from different areas, physics, mathematics, agricultural engineering, crop scientists and policy makers in United Nations. Most of the citation links do open, when you click on them. If it does not, copy and paste the link on any web browsers.

\section{Keywords}

Global Warming Prediction Models, Irrigation, Food, Land and Water Shortage and Few Sample Development Plans in Operation for Global Warming

\section{Introduction}

In recent years, climate change issues have become the focus of the world opinion. Early in the 1970s, scientists had put forward climate warming as a global environmental issue. In 1988 the World Meteorological Organization and the United Nations Environmental Program established "the Intergovernmental Panel on Climate Change (IPCC)" [1] [2]. In 1992, the Rio Conference on Environment and Development passed "the United Nations Framework Convention on Climate Change "(the so-called Convention on Climate Change)" which prescribed that developed countries should combat climate change and its adverse effects [3]. Moreover, the Convention declared that "responses to climate change should be coordinated with social and economic development in an integrated manner for the achievement of sustained economic growth and the eradication of poverty". The Convention recognized that all countries, especially developing countries, needed access to resources required to achieve sustainable social and economic development (Yang, 2012) [4]. In this context, the role of Agriculture is to meet the future challenges posed by food security by increasing production while conserving natural resources.

In the past, the increased demand for food has been satisfied by the expansion of agricultural land. Today, the prospects of increasing the gross cultivated area, in both the developed and developing countries are limited by the dwindling number of economically attractive sites for new large-scale irrigation and drainage projects. Therefore, any increase in agricultural production will necessarily rely largely on a more accurate estimation of crop water requirements on the one hand, and on major improvements in the operation, management and performance of existing irrigation and drainage systems, on the other hand.

The failings of present systems and the inability to sustainably exploit surface and ground water resources can be attributed essentially to poor planning, design, systems management and development. With a population that is expected to grow from 6 billion today to at least 8 billion by the year 2025, bold measures are essential if the problems of irrigation systems and shortage of food are to be avoided.

Concerning agricultural development, most of the world's 270 million ha of irrigated lands and 130 million ha of rain-fed lands with drainage facilities were developed on a step-by-step basis over the centuries. Many of the systems structures have aged or are deteriorating. Added to this, the systems have to withstand the pressures of 
changing needs, demands and social and economic evolution. Consequently, the infrastructures in most irrigated and drained areas need to be renewed or even replaced and thus redesigned and rebuilt, in order to achieve improved sustainable production. This process depends on a number of common and well-coordinated factors, such as advanced technology, environmental protection, institutional strengthening, economic and financial assessment and human resource development. Most of these factors are well known and linked to uncertainties associated with climate change, world market prices and international trade. All the above factors and constraints compel decision-makers to review the strengths and weaknesses of current trends in irrigation and drainage and rethink technology, institutional and financial patterns, research thrust and manpower policy, so that service levels and system efficiency can be improved in a sustainable manner.

\section{Irrigation Development and the Global Food Challenge}

To solve the above problems massive investments have been made over the last few decades by governments and individuals and a concerted effort by the International Community. The challenge was to provide enough food for 2 billion more people, while increasing domestic and industrial water demand. Different scenarios have been developed to explore a number of issues, such as the expansion of irrigated agriculture, massive increases in food production from rain-fed lands, water productivity trends and public acceptance of genetically modified crops. Opinions differ among the experts as to some of the above issues. However, there is broad consensus that irrigation can contribute substantially to increasing food production.

Today, the world's food production comes from a cultivated area of about 1.5 billion ha, representing $12 \%$ of the total land area (Schultz and De Wrachien, 2002) [5]. About 1.1 billion ha of cultivated land have no water management systems, though this area supplies $45 \%$ of food production. At present irrigation covers 270 million ha, i.e. $18 \%$ of the world's arable land. Overall, irrigated land contributes to $40 \%$ of agricultural output and employs about $30 \%$ of population in rural areas. It uses about $70 \%$ of water withdrawn from global river systems. About $60 \%$ of this water is used consumptively, the rest returning to the river systems. Drainage of rain-fed crops covers about 130 million ha, i.e. $9 \%$ of the world's arable land. In about 60 million ha of the irrigated lands there is a drainage system, as well. The 130 million or so hectares of drained rainfed land produces around $15 \%$ of crop output.

\subsection{Developments in Irrigation}

Over the last forty years, the irrigation has been a major contributor to the growth of food and fiber supply for a global population that has more than doubled, from 3 to over 6 billion people. Global irrigated area increased by around $2 \%$ a year in the 1960 s and 1970 s, slowing down to around $1 \%$ in the 1980 s, and lower still in the 1990s. Between 1965 and 1995 the world's irrigated land grew from 150 to 260 million ha. Nowadays it is increasing at a very slow rate because of the significant slowdown in new investments, combined with the loss of irrigated areas due to salination and urban encroachment.

Notwithstanding these achievements, today the majority of agricultural land (1.1 billion ha) still has no water management system. In this context it is expected that $90 \%$ of the increase in food production will have to come from existing cultivated land and only $10 \%$ from conversion from other uses. In the rainfed areas with no water management systems some improvements can be achieved with water harvesting and watershed management. However, in no way can the cultivated area with no water management contribute significantly to the required increase in food production. For this reason, the share of irrigated and drained areas in food production will have to increase. This can be achieved either by installing irrigation or drainage facilities in the areas without a system or by improving and modernizing existing systems. The International Commission on Irrigation and Drainage (ICID) estimates that within the next 25 years, this process may result in a shift of the contribution to the total food production to around $30 \%$ for the areas with no water management system, $50 \%$ for the areas with an irrigation system and $20 \%$ for the rainfed areas with a drainage system (Schultz, 2002) [6] [7]. Researchers/ readers interested in in irrigation and drainage and in crop production under changing climate conditions may like to read articles quoted in [35] [37] [40] [47].

\subsection{The Global Food Challenge}

As the world population continues to grow so too does the need to constantly increase the food production. Sev- 
eral actions are required to cope with this increasing demand. Globally, the core challenge must be to improve water productivity. Where land is limiting, yields per unit area must also be enhanced. These measures lead to two basic development directions [8]:

- increasing the yield frontier in those areas where present levels of production are close to their potential;

- closing the yield gap where considerable production gains can be achieved with current technology.

Based on the above assumptions, three models of food and irrigation water demand have been developed by non-governmental organizations for the time horizon 2025 (Plusquellec, 2002) [9]. These three models predict that present irrigated agriculture would have to increase by $15 \%-22 \%$. Moreover, water withdrawals for irrigation are also expected to increase at unprecedented rates, a major challenge considering that environmentalists argue that irrigation withdrawals should be reduced, as they have great expectations in the potential of biotechnology in agriculture.

Although the scenarios differ considerably, it is generally agreed that the world is entering the twenty-first century on the brink of a new food crisis, as ominous, but far more complex, that the famine it faced in the 1960s. Some analysts believe that what is needed is a new and "greener revolution" to increase productivity again and boost production. But the challenges are far more complex than simply producing more food, because global conditions have changed since the green revolution years.

\section{Climate and Climatic Change}

\subsection{The Greenhouse Effect}

Over the past centuries, the Earth's climate has been changing due to a number of natural processes, such as gradual variation in solar radiation, meteorite impacts and, more importantly, sudden volcanic eruptions in which solid matter, aerosols and gases are ejected into the atmosphere. Ecosystems have adapted continuously to these natural changes in climate, and flora and fauna have evolved in response to the gradual modifications to their physical surroundings, or have become extinct.

Human beings have also been affected by and have adapted to changes in local climate, which, in general terms, have occurred very slowly. Over the past century, however, human activities have begun to affect the global climate. These effects are due not only to population growth, but also to the introduction of technologies developed to improve the standard of living. Human-induced changes have taken place much more rapidly than natural changes. The scale of current climate forcing is unprecedented and can be attributed to greenhouse gas emissions, deforestation, urbanization, and changing land use and agricultural practices. The increase in greenhouse gas emissions into the atmosphere is responsible for the increased air temperature, and this, in turn, induces changes in the different components making up the hydrological cycle such as evapotranspiration rate, intensity and frequency of precipitation, river flows, soil moisture and groundwater recharge. Mankind will certainly respond to these changing conditions by taking adaptive measures such as changing patterns in land use. However, it is difficult to predict what adaptive measures will be chosen, and their socio-economic consequences [10]-[15].

Concern global patterns the following considerations can be drawn from analysis of the hydrologic and meteorological time series available:

- Average global temperature rose by $0.6^{\circ} \mathrm{C}$ during the $20^{\text {th }}$ century [16].

- 1990's was the warmest decade and 1998 the warmest year since 1861 [17].

- The extent of snow cover has decreased by $10 \%$ since the late 1960 s [18].

- Average global sea level rose between 0.1 and 0.2 meters during the $20^{\text {th }}$ century [19] [20].

- Precipitation increased by $0.5 \%$ to $1 \%$ per decade in the $20^{\text {th }}$ century over the mid and high latitudes of the northern hemisphere and by between $0.2 \%$ and $0.3 \%$ per decade over the tropics $\left(10^{\circ} \mathrm{N}\right.$ to $\left.10^{\circ} \mathrm{S}\right)[21]$.

- Precipitation decreased over much of the northern sub-tropical $\left(10^{\circ} \mathrm{N}\right.$ to $\left.30^{\circ} \mathrm{N}\right)$ land areas during the $20^{\text {th }}$ century by about $0.3 \%$ per decade [22].

- The frequency of heavy rain events increased by $2 \%$ to $4 \%$ in the mid and high latitudes of the northern hemisphere in the second half of the $20^{\text {th }}$ century. This could be the result of changes in atmospheric moisture, thunderstorm activity, large-scale storm activity, etc. [23]

- Over the $20^{\text {th }}$ century land areas experiencing severe drought and wetness have increased [23].

- Some regions of Africa and Asia recorded an increase in the frequency and intensity of drought in the last decade [24]. 
- $\mathrm{CO}_{2}$ concentration has increased by $31 \%$ since 1750 [25].

- $75 \%$ of $\mathrm{CO}_{2}$ emissions is produced by fossil fuel burning, the remaining $25 \%$ by land use change especially deforestation [25].

- Methane $\mathrm{CH}_{4}$ has increased by $151 \%$ since 1750 and continues to increase. Fossil fuel burning, livestock, rice cultivation and landfills are responsible for emissions [26].

- Nitrous Oxide $\left(\mathrm{N}_{2} \mathrm{O}\right)$ has increased by $17 \%$ since 1750 and continues to increase. This gas is produced by agriculture, soils, cattle feed lots and the chemical industry [27].

- Stratospheric Ozone $\left(\mathrm{O}_{3}\right)$ layer has been depleting since 1979 [28].

\subsection{Climate Change Scenarios}

Current scientific research is focused on the enhanced greenhouse effect as the most likely cause of climate change in the short-term. Until recently, forecasts of anthropogenic climate change have been unreliable, so that scenarios of future climatic conditions have been developed to provide quantitative assessments of the hydrologic consequences in some regions and/or river basins. Scenarios are "internally-consistent pictures of a plausible future climate" (Wigley et al., 1986) [29]. These scenarios can be classified into three groups:

- hypothetical scenarios;

- climate scenarios based on General Circulation Models (GCMs) [30];

- scenarios based on reconstruction of warm periods in the past (paleoclimatic reconstruction).

The plethora of literature on this topic has been recently summarized by the Intergovernmental Panel on Climate Change [31].

The scenarios of the second group have been widely utilized to reconstruct seasonal conditions of the change in temperature, precipitation and potential evapotraspiration at basin scale over the next century. GCMs are complex three-dimensional computer-based models of the atmospheric circulation, which provide details of changes in regional climates for any part of the Earth. Until recently, the standard approach has been to run the model with a nominal "pre-industrial" atmospheric carbon dioxide $\left(\mathrm{CO}_{2}\right)$ concentration (the control run) and then to rerun the model with doubled (or sometimes quadrupled) $\mathrm{CO}_{2}$ (the perturbed run). This approach is known as "the equilibrium response prediction". The more recent and advanced GCMs are, nowadays, able to take into account the gradual increase in the $\mathrm{CO}_{2}$ concentration through the perturbed run. However, current results are not sufficiently reliable.

\section{Climate Change and Irrigation Requirements}

Agriculture is a human activity that is intimately associated with climate. It is well known that the broad patterns of agricultural growth over long time scales can be explained by a combination of climatic, ecological and economic factors. Modern agriculture has progressed by weakening the downside risk of these factors through irrigation, the use of pesticides and fertilizers, the substitution of human labor with energy intensive devices, and the manipulation of genetic resources. A major concern in the understanding of the impacts of climate change is the extent to which world agriculture will be affected. Thus, in the long term, climate change is an additional problem that agriculture has to face in meeting global and national food requirements. This recognition has prompted recent advances in the coupling of global vegetation and climate models.

In the last decade, global vegetation models have been developed that include parameterizations of physiological processes such as photosynthesis, respiration, transpiration and soil water in-take (Bergengren et al.) [32]. These tools have been coupled with General Circulation Models (GCMs) and applied to both paleoclimatic and future scenarios (Doherty et al. and Levis et al. [33] [34]. The use of physiological parameterizations allows these models to include the direct effects of changing $\mathrm{CO}_{2}$ levels on primary productivity and competition, along with the crop water requirements. In the next step the estimated crop water demands could serve as input to agro-economic models which compute the irrigation water requirements (IR), defined as the amount of water that must be applied to the crop by irrigation in order to achieve optimal crop growth.

On the global scale, scenarios of future irrigation water use have been developed by Seckler et al. [35] and Alcamo et al. (2000). Alcamo et al. employed the raster-based Global Irrigation Model (GIM) [37] of Döll and Siebert (2002) [36], with a spatial resolution of 0.50 by 0.50 . This model represents one of the most advanced tools today available for exploring the impact of climate change on IR at worldwide level.

More recently, the GIM has been applied to explore the impact of climate change on the irrigation water requirements of those areas of the globe equipped for irrigation in 1995 (Döll, 2002) [36]. Estimates of long-term 
average climate change have been taken from two different GCMs:

- the Max Planck Institute for Meteorology (MPI-ECHAM4), Germany;

- the Hadley Centre for Climate Prediction and Research (HCCPR-CM3), UK.

The following climatic conditions have been computed:

- present-day long-term average climatic conditions, i.e. the climate normal 1961-1990 (baseline climate) [38];

- future long-term average climatic conditions of the 2020s and 2070s (climatic change) [39].

For the above climatic conditions, the GIM computed both the net and gross irrigation water requirements in all 0.50 by 0.50 raster cells with irrigated areas. "Gross irrigation requirement" is the total amount of water that must be applied such that evapotraspiration may occur at the potential rate and optimum crop productivity may be achieved. Only part of the irrigated water is actually used by the plant and evapotranspirated. This amount, i.e. the difference between the potential evapotranspiration and the evapotranspiration that would occur without irrigation, represents the "net irrigation requirement" (IRnet. [40]).

The simulations show that irrigation requirements increase in most irrigated areas north of $40^{\circ} \mathrm{N}$, by up to $30 \%$, which is mainly due to decreased precipitation, in particular during the summer. South of this latitude, the pattern becomes complex. For most of the irrigated areas of the arid northern part of Africa and the Middle East, IRnet diminishes. In Egypt, a decrease of about $50 \%$ in the southern part is accompanied by an increase of about $50 \%$ in the central part [41]. In central India, baseline IRnet values of $250-350 \mathrm{~mm}$ are expected to more than double by the 2020s [42]. In large parts of China the impact of climate change is negligible (less than 5\%), with decreases in northern China, as precipitation is assumed to increase [43]. When the cell-specific net irrigation requirements are summed up over the world regions, increases and decreases of the cell values caused by climate change almost average out, increasing by $3.3 \%$ in the 2020 s and by $5.5 \%$ in the 2070 s [5] [40] (Table 1). Climate Change and Water Availability.

Table 1. The simulations also show that in areas equipped for irrigation in 1995 IRnet is likely to increase in $66 \%$ of these areas by the 2020 s and in $62 \%$ by the 2070 s.

\begin{tabular}{|c|c|c|c|c|c|c|c|}
\hline & \multicolumn{7}{|c|}{ Irrigated Cropping Long-Term Average IRnet, $\mathrm{km}^{3} / \mathrm{yr}$} \\
\hline & $\begin{array}{l}\text { Area } 1995, \\
1000 \mathrm{~km}^{2}\end{array}$ & Intensity & Baseline & $\begin{array}{c}2020 \mathrm{~s} \\
\text { ECHAM4 }\end{array}$ & HadCM3 & 2070s ECHAM4 & HadCM3 \\
\hline Canada & 7.1 & 1.0 & 2.4 & 2.9 & 2.7 & 3.3 & 2.9 \\
\hline USA & 235.6 & 1.0 & 112.0 & 120.6 & 117.9 & 123.0 & 117.9 \\
\hline Central America & 80.2 & L.O & 17.5 & 17.0 & 17.6 & 18.1 & 19.7 \\
\hline South America & 98.3 & LO & 26.6 & 27.1 & $27 . \mathrm{S}$ & 28.2 & 29.1 \\
\hline Northern Africa & 59.4 & LS & 66.4 & 62.7 & 65.3 & 56.0 & 57.7 \\
\hline Western Africa & 8.3 & 1.0 & 2.5 & 2.2 & 2.4 & 2.4 & 2.6 \\
\hline Eastern Africa & 35.8 & 1.0 & 12.3 & 13.1 & 12.2 & 14.5 & 14.3 \\
\hline Southern Africa & 18.6 & 1.0 & 7.1 & 7.0 & 7.4 & 6.4 & 7.2 \\
\hline OECD Europe & 118.0 & 1.0 & 52.4 & 55.8 & 55.2 & 56.5 & 57.8 \\
\hline Eastern Europe & 49.4 & LO & 16.7 & 18.4 & 19.0 & 19.7 & 22.1 \\
\hline Former U.S.S.R. & 218.7 & 0.8 & 104.6 & 106.6 & 112.1 & 104.4 & 108.7 \\
\hline Middle East & 185.3 & 1.0 & 144.7 & 138.7 & 142.4 & 126.5 & 137.8 \\
\hline South Asia & 734.6 & L3 & 366.4 & 389.8 & 400.4 & 410.7 & 422.0 \\
\hline East Asia & 492.5 & 1.5 & 123.8 & 126.0 & 126.6 & 131.3 & 127.1 \\
\hline Southeast Asia & 154.4 & 1.2 & 17.1 & 20.3 & 18.8 & 30.4 & 28.6 \\
\hline Oceania & 26.1 & L5 & 17.7 & 17.8 & 17.6 & 18.2 & 19.7 \\
\hline Japan & 27.0 & L5 & 1.3 & 1.3 & L8 & 1.4 & 1.5 \\
\hline World & 2549.1 & & 1091.5 & 1127.5 & 1147.0 & 1151.0 & 1176.8 \\
\hline
\end{tabular}

Irrigated areas of 1995, under 1961-1990 average observed climate ("baseline"), and scaled with MPI-ECHAM4 or HCCPR-CM3 climate change scenarios for 2020-2029 ("2020s") and 2070-2090 ("2070s"). 
In order to assess the problem of water scarcity, the appropriate averaging units are not world regions but river basins.

Climate predictions from four state-of-the-art General Circulation Models were used to assess the hydrologic sensitivity to climate change of nine large, continental river basins (Nijssen et al., 2001). The river basins were selected on the basis of the desire to represent a range of geographic and climatic conditions. Four models have been used:

- the Hadley Centre for Climate Prediction and Research (HCCPR-CM2), UK;

- the Hadley Centre for Climate Prediction and Research (HCCPR-CM3), UK;

- the Max Planck Institute for Meteorology (MPI-ECHAM4), Germany;

- the Department of Energy (DOE-PCM3), USA.

All predicted transient climate response to changing greenhouse gas concentrations and incorporated modern land surface parameterizations. The transient emission scenarios differ slightly from one model to another, partly because they represent greenhouse gas chemistry differently.

Changes in basin-wide, mean annual temperature and precipitation were computed for three decades in the transient climate model runs $(2025,2045$ and 2095) and hydrologic model simulations were performed for decades centered on 2025 and 2045 [43].

The main conclusions are summarized below.

- All models predict a warming for all nine basins, but the amount of warming varies widely between the models, especially for the longer time horizon. The greatest warming is predicted to occur during the winter months in the highest latitudes [44]. Precipitation generally increases for the northern basins, but the signal is mixed for basins in the mid-latitudes and tropics, although on average slight precipitation increases are predicted [45].

- The largest changes in hydrological cycle are predicted for the snow-dominated basins of mid to higher latitudes, as a result of the greater amount of warming that is predicted for these regions. The presence or absence of snow fundamentally changes the water balance, due to the fact that water stored as snow during the winter does not become available for runoff or evapotranspiration until the following spring's melt period [45].

- Globally, the hydrological response predicted for most of the basins in response to the GCMs predictions is a reduction in annual stream flow in the tropical and mid-latitudes. In contrast, high-latitude basins tend to show an increase in annual runoff, because most of the predicted increase in precipitation occurs during the winter, when the available energy is insufficient for an increase in evaporation. Instead, water is stored as snow and contributes to stream flow during the subsequent melt period [45].

\section{Planning and Design of Irrigation Systems under Climate Change}

Uncertainties as to how the climate will change and how irrigation systems will have to adapt to these changes, are challenges that planners and designers will have to cope with. In view of these uncertainties, planners and designers need guidance as to when the prospect of climate change should be embodied and factored into the planning and design process (De Wrachien and Feddes, 2004) [46]. An initial question is whether, based on GCM results or other analyses, there is reason to expect that a region's climate is likely to change significantly during the life of a system. If significant climate change is thought to be likely, the next question is whether there is a basis for forming an expectation about the likelihood and nature of the change and its impacts on the infrastructures [47].

The suitability and robustness of an infrastructure can be assessed either by running "what if scenarios" that incorporate alternative climates or through synthetic hydrology by translating apparent trends into enhanced persistence [46].

When there are grounds for formulating reasonable expectations about the likelihood of climate changes, the relevance of these changes will depend on the nature of the project under consideration. Climate changes that are likely to occur several decades from now will have little relevance for decisions involving infrastructure development or incremental expansion of existing facilities' capacity. Under these circumstances planners and designers should evaluate the options under one or more climate change scenario to determine the impacts on the project's net benefits. If the climate significantly alters the net benefits, the costs of proceeding with a decision assuming no change can be estimated. If these costs are significant, a decision tree can be constructed for eva- 
luating the alternatives under two or more climate scenarios (Hobbs et al., 1997) [48].

Delaying an expensive and irreversible project may be a competitive option, especially in view of the prospect that the delay will result in a better understanding as to how the climate is likely to change and impact the effectiveness and performance of the infrastructure [46].

Aside from the climate change issue, the high costs of and limited opportunities for developing new large scale projects, have led to a shift away from the traditional, fairly inflexible planning principles and design criteria for meeting changing water needs and coping with hydrological variability and uncertainty. Efficient, flexible works designed for current climatic trends would be expected to perform efficiently under different environmental conditions. Thus, institutional flexibility that might complement or substitute infrastructure investments is likely to play an important role in irrigation development under the prospect of global climatic change. Frederick et al. (1997) proposed a five-step planning and design process for water resource systems, for coping with uncertain climate and hydrologic events, and potentially suitable for the development of large irrigation schemes [49].

If climate change is recognized as a major planning issue (first step), the second step in the process would consist of predicting the impacts of climate change on the region's irrigated area. The third step involves the formulation of alternative plans, consisting of a system of structural and/or non-structural measures and hedging strategies that address, among other concerns, the projected consequences of climate change. Non-structural measures that might be considered include modification of management practices, regulatory and pricing policies. Evaluation of the alternatives, in the fourth step, would be based on the most likely conditions expected to exist in the future with and without the plan [50]. The final step in the process involves comparing the alternatives and selecting a recommended development plan. Here in the authors have cited some sample plans by various governemnts [47]-[99]. We have listed a reference [79], to find the proper names for various countries. If the reader likes to find a climate action plan for his country of interest, just go to google.com and type in or search for climate action for country of your interest. We have cited climate action plans proposed by few countries like USA, India, China, and Europen contintent.

The planning and design process needs to be sufficiently flexible to incorporate consideration of and responses to many possible climate impacts. Introducing the potential impacts of and appropriate responses to climate change in planning and design of irrigation systems can be both expensive and time consuming. The main factors that might influence the worth of incorporating climate change into the analysis are the level of planning (local, national, international), the reliability of GCMs, the hydrologic conditions, the time horizon of the plan or life of the project [94] [95].

\section{Concluding Remarks}

- Agriculture will have to meet the future challenges posed by food security by increasing production while conserving natural resources.

- With a population that is expected to grow from 6 billion today to at least 8 billion by the year 2025 [100] [101], bold measures are essential if the problems of irrigation systems and shortage of food are to be avoided.

- Different scenarios have been developed to explore a number of issues, such as the expansion of irrigated agriculture, massive increases in food production from rainfed lands and water productivity trends. Opinions differ among experts as to some of the above issues. However, there is broad consensus that irrigation can contribute substantially to increasing food production in the years to come.

- Most of the world's irrigation systems were developed on a step-by-step basis over the centuries and were designed for a long life (50 years or more), on the assumption that climatic conditions would not change. This will not be so in the future, due to global warming and the greenhouse effect. Therefore, engineers and decision-makers need to systematically review planning principles, design criteria, operating rules, contingency plans and water management policies.

- Uncertainties as to how the climate will change and how irrigation systems will have to adapt to these changes are issues that water authorities are compelled to address. The challenge is to identify short-term strategies to cope with long-term uncertainties. The question is not what the best course for a project is over the next fifty years or more, but rather, what is the best direction for the next few years, knowing that a prudent hedging strategy will allow time to learn and change course. 
- The planning and design process needs to be sufficiently flexible to incorporate consideration of and responses to many possible climate impacts. The main factors that will influence the worth of incorporating climate change into the process are the level of planning, the reliability of the forecasting models, the hydrological conditions and the time horizon of the plan or the life of the project.

The development of a comprehensive approach that integrates all these factors into irrigation project selection requires further research on the processes governing climate changes, the impacts of increased atmospheric carbon dioxide on vegetation and runoff, the effect of climate variables on crop water requirements and the impacts of climate on infrastructure performance.

\section{Acknowledgements}

Heartfelt acknowlegements to all the authors, cited in this global warming review article. Because of the enormous challenge that our human race is going through in this 21 st century, we the authors of this article, took liberty to share the knowledge and findings and plans that many of you have posted on the web sites. I hope we all scientists of diffrent countries share our know how in advance before we face the worst scenerios of human, plants and nature suffering due to our own negligence or unawareness.

\section{References}

[1] Intergovernmental Climate Change (1988) https://www.ipcc.ch/organization/organization.shtml

[2] Intergovernmental Climate Change Resolutions https://www.ipcc.ch/docs/WMO_resolution4_on_IPCC_1988.pdf

[3] Climate Change 2001: Synthesis Report. http://www.ipcc.ch/ipccreports/tar/vol4/index.php?idp=204

[4] Yang, Z.W. (2012) The Right to Carbon Emission: A New Right to Development. American Journal of Climate Change, 1, 108-116. http://dx.doi.org/10.4236/ajcc.2012.12009

[5] De Wrachien, D. and Feddes, R. (2003) Drainage Development in a Changing Environment: Overview and Challenge. 9th International Drainage Workshop Drainage for a Secure Environment and Food Supply, Utrecht, 10-13 September 2003, 1-31.

http://www.researchgate.net/publication/275977046 Drainage Development in a Changing Environment Overvie w_and Challenges

[6] Schultz, B. (2002) Opening Address. Proceedings of the 18th Congress on Irrigation and Drainage (ICID). Montreal, 21-28 July 2002, 7-23. http://afeid.montpellier.cemagref.fr/old/Montreal2002final.pdf

[7] Schultz, B. and De Wrachien, D. (2002) Irrigation and Drainage Systems. Research and Development in the 21st Century. Irrigation and Drainage, 51, 311-327. http://dx.doi.org/10.1002/ird.67

[8] Molden, D., et al. (2007) Trends in Water and Agricultural Development. IWMI Part 2 Ch2-3 final. indd 57. http://www.iwmi.cgiar.org/assessment/Water\%20for\%20Food\%20Water\%20for\%20Life/Chapters/Chapter\%202\%20T rends.pdf

[9] Plusquellec, H. (2002) Is the Daunting Challenge of Irrigation Achievable? Irrigation and Drainage, 51, 185-198. http://dx.doi.org/10.1002/ird.51

[10] Stoddard, J.L., et al. (1999) Letters to Nature. Regional Trends in Aquatic Recovery from Acidification in North America and Europe. Nature, 401, 575-578. http://www.nature.com/nature/journal/v401/n6753/full/401575a0.html

[11] Schils, R., Kuikman, P., Liski, J., Van Oijen, M., Smith, P., Webb, J., et al. (2008) Review of Existing Information on the Interrelations between Soil and Climate Change. (ClimSoil). Final Report. Center for Ecology and Hydrology. Natural Environmental Research Council. European Commission, Brussels, 1-208. http://nora.nerc.ac.uk/6452/1/climsoil_report_dec_2008.pdf http://ec.europa.eu/environment/soil/review en.htm

[12] Walther, G.-R., Post, E., Convey, P., Menzel, A., Parmesan, C., Beebee, T.J.C., et al. (2002) Ecological Responses to Recent Climate Change. Nature, 416, 389-395. http://www.nature.com/nature/journal/v416/n6879/full/416389a.html http://dx.doi.org/10.1038/416389a

[13] Seinfeld, J.H. and Pandis, S.N. (2012) Atmospheric Chemistry and Physics: From Air Pollution to Climate Change. John Wiley \& Sons, 1-1232. ISBN: 978-0-471-72018-8.

[14] US Department of Interior and US Geological Survey (2013) Artificial Groundwater Recharge. http://water.usgs.gov/ogw/artificial_recharge.html

[15] De Wrachien, D., Rag, A.R. and Giordano, A. (2003) Climate Change Land Degradation and Desertification in the Mediterranean Environment. NATO-CCMS Workshop. https://air.unimi.it/bitstream/2434/28644/1/Deser5rel.doc 
http://www.epa.gov/esd/land-sci/desert/images/book-of-abstracts-nato-workshop.pdf

[16] World Nuclear Association (2014) Climate Change-The Science. Greenhouse Effect. http://www.world-nuclear.org/info/Energy-and-Environment/Climate-Change---The-Science/

[17] Inter-Governmental Panel on Climate Change (IPCC) (2001) Climate Change 2001: The Scientific Basis. The Observed Changes in the Climate System Is the Earth's Climate Changing?

http://www.ipcc.ch/ipccreports/tar/vol4/082.htm

http://www.ipcc.ch/publications_and_data/publications_and_data reports.shtml

[18] Inter-Governmental Panel on Climate Change (IPCC) (2001) Working Group I: The Scientific Basis. Observed Changes in Precipitation and Atmospheric Moisture. http://www.ipcc.ch/ipccreports/tar/wg1/013.htm

[19] Gammon, R. (Guest Lecturer) (2001) Climate Models over the Next 100 Years. http://www.atmos.washington.edu/2001Q4/211/notes_climatechange.html

[20] USGCRP (2014) Our Changing Planet, Indicators of Change, Adapting to Change. USGCRP Released the Third National Climate Assessment, the Authoritative and Comprehensive Report on Climate Change and Its Impacts in the United States. http://www.globalchange.gov/

[21] Cline, W.R. (2004) Meeting the Challenge of Global Warming. Copenhagen Consensus 2004 Project. http://www.copenhagenconsensus.com/sites/default/files/CP\%2B-\%2BGlobal\%2BWarming\%2BFINISHED.pdf

[22] Albritton, D.L., Allen, M.R., Baede, A.P.M., Church, J.A., Cubasch, U., Dai, X., et al. (2001) Summary for Policymakers. A Report of Working Group I of the Intergovernmental Panel on Climate Change (IPCC). http://www.atmos.washington.edu/2003Q4/211/articles_required/IPCC_2001_SPM.pdf

[23] Inter-Governmental Panel on Climate Change (IPCC) (2001) Working Group I: The Scientific Basis. Droughts and Wet Spells. http://ipcc.ch/ipccreports/tar/wg1/092.htm

[24] Speranskaya, O., Eco-Accord and Olesen, G.B. (2001) Climate Change and Energy. The Climate Change Has Been Proven by Soli Scientific Facts. Published by ECO-Accord, Moscow, and Forum for Energy and Development, Denmark. http://www.ecoaccord.org/climate/2001-engl/1.htm

[25] Environmental Protection Agency (EPA) (2013) Overview of Greenhouse Gases. Carbon Dioxide Emissions. http://www.epa.gov/climatechange/ghgemissions/gases/c02.html

[26] De Wrachien, D., Ragab, R. and Giordano, A. (2006) Climate Change, Land Degradation, and Desertification in the Mediterranean Environment. A Security Issue. NATO Security through Science Series, Vol. 3, 353-371. http://link.springer.com/chapter/10.1007\%2F1-4020-3760-0_16\#page-1

[27] IPCC Assessment Report on Climate Change (2013) What Causes This Climate Change? Intergovernmental Panel on Climate Change (IPCC). http://www.greenfacts.org/en/climate-change-ar3/1-3/climate-change-2.htm

[28] Earth System Research Laboratory Stratospheric Ozone Layer Depletion and Recovery. U.S. Department of Commerce, National Oceanic and Atmospheric Administration, Earth System Research Laboratory. http://www.esrl.noaa.gov/research/themes/o3/

[29] Wigley, T.M.L., Jones, P.D. and Kelly, P.M. (1986) Empirical Climate Studies. Warm World Scenarios and the Detection of Climate Change Induced by Radioactively Active Fases. In: Bolin, B., Doos, B.R., Jager, J. and Warrich, R.A., Eds., The Greenhouse Effect, Climatic Change and Ecosystems, SCOPE 26, Wiley Publisher, New York, 271-322.

[30] Numerous Scientists (2015) The Discovery of Global Warming. General Circulation Models of Climate. http://www.aip.org/history/climate/GCM.htm

[31] Scott, D.B. and Collins, E.S. (1996) Late Mid-Holocene Sea-Level Oscillation: A Possible Cause. Quaternary Science Reviews, 15, 851-856. http://www.sciencedirect.com/science/article/pii/S0277379196000637 http://dx.doi.org/10.1016/s0277-3791(96)00063-7

[32] Bergengren, J.C., Thompson, S.L., Pollard, D. and Deconto, R.M. (2001) Modeling Global Climate-Vegetation Interactions in a Doubled $\mathrm{CO}_{2}$ World. Climatic Change, 50,31-75.

http://link.springer.com/article/10.1023/A:1010609620103\#page-1 http://dx.doi.org/10.1023/A:1010609620103

[33] Doherty, R., Kutzbach, J., Foley, I. and Pollard, D. (2000) Fully-Coupled Climate/Dynamical Vegetation Model Simulation over Northern Africa during Mid-Holocene. Climate Dynamics, 16, 561-573.

http://www.research.ed.ac.uk/portal/en/publications/fully-coupled-climatedynamical-vegetation-model-simulations-ove r-northern-africa-during-the-midholocene $\% 28 \mathrm{e} 07 \mathrm{a} 8 \mathrm{ccb}$-e $5 \mathrm{bf}-406 \mathrm{e}-9 \mathrm{a} 45$-baec $5701 \mathrm{ced} 5 \% 29 /$ export.html http://dx.doi.org/10.1007/s003820000065

[34] Levis, S., Foley, J.A. and Pollard, D. (2000) Large-Scale Vegetation Feedbacks on a Double $\mathrm{CO}_{2}$ Climate. Journal of Climate, 13, 1313-1325.

http://journals.ametsoc.org/doi/abs/10.1175/1520-0442\%282000\%29013\%3C2217\%3ARTCSTC\%3E2.0.CO\%3B2 
[35] Seckler, D., Amarasinghe, V., Molden, D., de Silva, R. and Barker, R. (1997) World Water Demand and Supply, 1990 to 2025: Scenarios and Issues. Research Report 19, IWMI, Colombo, Sri Lanka. http://dlc.dlib.indiana.edu/dlc/bitstream/handle/10535/4351/REPORT19.pdf?sequence=1

[36] Döll, P. (2002) Impact of Climate Change and Variability on Irrigation Requirements: A Global Perspective. Climatic Change, 54, 269-293. http://link.springer.com/article/10.1023/A\%3A1016124032231 http://dx.doi.org/10.1023/A:1016124032231

[37] Alcamo, J., Henrish, T. and Rösch, T. (2000) World Water in 2025. Global Modeling and Scenario Analysis for the World Commission on Water for the 21st Century. Kassel World Water Series Report 2. Centre for Environmental Systems Research, University of Kassel, Germany. http://www.usf.uni-kassel.de/usf/archiv/dokumente/kwws/kwws.2.pdf

[38] The Climatic Research Unit Global Climate Dataset The Mean 1961-90 Climatology. Intergovernmental Climate Change (IPCC). http://www.ipcc-data.org/observ/clim/cru_climatologies.html

[39] Charabi, Y. and Al-Khoudh, S. (2013) Projection of Future Changes in Rainfall and Temperature Patterns in Oman. Journal of Earth Science \& Climatic Change, 4, 154.

http://omicsonline.org/projection-of-future-changes-in-rainfall-and-temperature-patterns-in-oman-2157-7617.1000154. pdf

[40] Döll, P. (2002) Impact of Climate Change and Variability on Irrigation Requirements: A Global Perspective. Climatic Change, 54, 269-293. https://www.uni-frankfurt.de/45217733/doell ClimaticChange2002 irrigation.pdf http://dx.doi.org/10.1023/A:1016124032231

[41] El-Nahrawy, M.A. (2011) Egypt. Country Pasture/Forage Resource Profile. http://www.fao.org/ag/AGP/AGPC/doc/Counprof/Egypt/Egypt.html

[42] De Wrachien, D. (2003) Global Warming and Irrigation Development. A World-Wide View. International Scientific Conference on Agricultural Water Management and Mechanization Factors for Sustainable Agriculture, Sofia, 8-10 October 2003. https://air.unimi.it/bitstream/2434/28642/1/Sofiarel.doc

[43] IPCC (2007) IPCC Fourth Assessment Report: Climate Change. Working Group II: Impacts, Adaptation and Vulnerability. How Will Climate Change Affect the Balance of Water Demand and Water Availability. https://www.ipcc.ch/publications and data/ar4/wg2/en/ch3s3-5-1.html

[44] Nijssen, B., O’Donnell, G.M., Hamlet, A.F. and Lettenmaier, D.P. (2001) Hydrologic Sensitivity of Global Rivers to Climate Change. Climatic Change, 50, 143-175. http://climate.org/resources/climate-impacts/hydro/abstracts/index.html

[45] De Wrachien, D., Ragab, R., Hamdyand, A. and Trisorio Liuzz, G. (2004) Conference Paper. Conference: Food Security under Water Scarcity in the Middle East: Problems and Solutions. http://www.researchgate.net/profile/Daniele_Wrachien/publication/275980991_Global_Warming_Water_Scarcity_and Food Security in the Mediterranean Environment/links/554dc38608ae93634ec59c8c

[46] Frederick, K.D. (2011) Principles and Concepts for Water Resources Planning under Climate Uncertainty. http://opensiuc.lib.siu.edu/cgi/viewcontent.cgi?article=1238\&context=jcwre

[47] Hobbs, B.F., Chao, P.T. and Venkatesh, B.M. (1997) Using Decision Analysis to Include Climate Change in Water Resources in Decision Making. Climatic Change, 37, 177-202. http://dx.doi.org/10.1023/A:1005376622183

[48] Frederick, K.D., Major, D.C. and Stakhiv, E.Z. (1997) Water Resources Planning Principles and Evaluation Criteria for Climate Change. Climatic Change, 37, 291-313. http://link.springer.com/chapter/10.1007/978-94-017-1051-0_16 http://dx.doi.org/10.1023/A:1005332807162

[49] Wrachien Daniele D. Wrachien, Feddes, R., Ragab, R. and Ba (2004) Agricultural Development and Food Security under Climate Uncertainty. New Medit N. 3, 12-19. http://www.iamb.it/share/img_new_medit_articoli/140_12wrachien.pdf

[50] Reed, M.S., Fraser, E.D.G. and Dougill, A.J. (2006) An Adaptive Learning Process for Developing and Applying Sustainability Indicators with Local Communities. Ecological Economics, 59, 406-418.

http://www.sciencedirect.com/science/article/pii/S0921800905005161 http://dx.doi.org/10.1016/j.ecolecon.2005.11.008

[51] Jankowsk, P. (1995) Integrating Geographical Information Systems and Multiple Criteria Decision-Making Methods. International Journal of Geographical Information Systems, 9, 251-273. http://www.tandfonline.com/doi/abs/10.1080/02693799508902036

[52] Rasmussen, B. and Lyons, W.M. (2008) Statewide and Regional Transportation Planning. 2-Puget Sound Regional Council Case Study. Integration of Climate Change Considerations into the Seattle Metropolitan Area Transportation Planning Process. http://climate.dot.gov/state-local/integration/chapter_02.html

[53] California (2010) Adaptation Strategies A Guide Book for Global Warming from California. 1-121. 
http://www.climatechange.ca.gov/ecref/docs/CCSAdaptationGuidebook2011.pdf

[54] The Center for Climate Strategies (2015) Adaptation Guidebook Comprehensive Climate Action. http://www.climatestrategies.us/

[55] EPA (United States Environmental Protection Agency) (2014) Being Prepared for Climate Change. A Workbook for Developing Risk-Based Adaptation Plans.

http://www2.epa.gov/sites/production/files/2014-09/documents/being_prepared_workbook_508.pdf

[56] Global Policy Form (2013) Climate Change and It's Impact on Poor Famers.

https://www.globalpolicy.org/social-and-economic-policy/the-environment/climate-change.html

[57] European Climate Adaption Form (2015) About Climate Change Adaptation in Europe. http://climate-adapt.eea.europa.eu/home

[58] Sala, S., ICT for Development and Environment Specialist (2011) The Role of Information and Communication Technologies for Community-Based Adaptation to Climate Change. Food and Agriculture Organization of the United Nations, Rome, 2010. http://www.fao.org/uploads/media/ap606e_2.pdf

[59] Andrea Egan, N. (2011) Preparing Low-Emission Climate-Resilient Development Strategies. A UNDP GuidebookVersion 1. United Nations Development Programme, Anvil Creative, 1-24.

http://www.undp.org/content/dam/undp/library/Environment\%20and\%20Energy/Climate\%20Strategies/UNDP-LECR DS-Guidebook-v17-web.pdf http://www.undp.org/content/undp/en/home/librarypage.html

[60] US Army of Corps of Engineers (2009) Shared Vision Planning. Collaborative Planning Toolkit—A Web-Based Resource Guide with Extensive Hyperlinks to Existing Literature.

http://www.sharedvisionplanning.us/CPToolkit/PrintAllContent.asp

[61] Legrand Energy Efficiency. Social Governance (2015) Sustaniable Development. http://www.legrand.com/EN/sustainable-development-description_12847.html

[62] OREGON Scenario Planning Guidelines Resources for Developing and Evaluating Alternative Land Use and Transportation Scenarios.

http://www.oregon.gov/ODOT/TD/OSTI/docs/Scenario\%20Planning\%20Guidelines/ODOT-Guidelines-April2013-red .pdf

[63] Morrisette, P.M. (1989) The Evolution of Policy Responses to Stratospheric Ozone Depletion. Natural Resources Journal, 29, 793-820. http://www.ciesin.org/docs/003-006/003-006.html

[64] Sathaye, J., Najam, A., Cocklin, C., Heller, T., Lecocq, F., Llanes-Regueiro, J., et al. (2007) Sustainable Development and Mitigation. In Climate Change 2007: Mitigation. Contribution of Working Group III to the Fourth Assessment Report of the Intergovernmental Panel on Climate Change. In: Metz, B., Davidson, O.R., Bosch, P.R., Dave, R. and Meyer, L.A., Eds., Sustainable Development and Mitigation, Chap. 12, Cambridge University Press, Cambridge, United Kingdom and New York, 693-743. https:/www.ipcc.ch/pdf/assessment-report/ar4/wg3/ar4-wg3-chapter12.pdf

[65] Kelly, H.L. and His Group (2012) Urban Watershed Framework. A New Approach to Stormwater Management in San Francisco. 1-35. http://sfwater.org/Modules/ShowDocument.aspx?documentid=2552

[66] US Global Research Program. Introduction to Our Changing Climate. http://nca2014.globalchange.gov/report/our-changing-climate/introduction

[67] US Global Research Program. Deision Support: Connecting Science, Risk Perception, and Decisions. http://nca2014.globalchange.gov/report/response-strategies/decision-support

[68] International Encyclopedia of the Social Sciences (2008) Global Warming. http://www.encyclopedia.com/topic/global_warming.aspx

[69] Pawlenty, T. (2007) Next Generation Energy Initiatives to Reduce Greenhouse Gases. http://www.pca.state.mn.us/index.php/view-document.html?gid=20235

[70] Asian Develoment Bank (ADB) (2012) Environment Safeguards. A Good Practice Sourcebook Draft Working Document.

http://www.adb.org/sites/default/files/institutional-document/33739/files/environment-safeguards-good-practices-sourc ebook-draft.pdf

[71] McLuhan, M. and Fiore, Q., and His Group (2012) SSHRC —Imagining Canada's Future-Readings. In: SchwarzHerion, O. and Omran, A. Eds., Strategies towards the New Sustainability Paradigm: Managing the Great Transition to Sustainable Global Democracy, (e-Book) Springer. http://slab.ocadu.ca/sshrc-imagining-canadas-future-readings

[72] Leach, M., Rockström, J., Raskin, P., Scoones, I., Stirling, A.C., Smith, A., Thompson, J., Millstone, E., Ely, A., Arond, E., Folke, C. and Olsson, P. (2012) Transforming Innovation for Sustainability Ecology and Society. Ecology and Society, 17, 11. 
[73] Bodansky, D. (2009) Climate Change: Top 10 Precepts for U.S. Foreign Policy. http://www.rff.org/RFF/Documents/IB\%2009-01.pdf

[74] Capellán-Pérez, I., Mediavill, M., de Castro, C., Carpintero, Ó. and Miguel, L.J. (2015) More Growth? An Unfeasible Option to Overcome Critical Energy Constraints and Climate Change. http://www.eis.uva.es/energiasostenible/wp-content/uploads/2015/05/AAM More growth SS 2015.pdf http://link.springer.com/article/10.1007\%2Fs11625-015-0299-3

[75] Worcester Polytechnique Institute WPI. Social Science \& Policy Studies. Domestic Economic Problems and Policies such as Development Planning. http://www.wpi.edu/academics/ssps/ugrad-courses.html

[76] Your Internet Guide to Understand Policy Issues (2009) Environmmental Policy. What Are the Most Recent Developments Regarding Environmental Matters? http://www.newsbatch.com/environment.htm

[77] Alaska (2011) The Final and Draft Reports of the Climate Change Advisory Groups. http://www.climatechange.alaska.gov/

[78] Philippines: M \& E System for the National Climate Change (2011) National Climate Change Action Plan 2011-2028. http://adaptationmarketplace.org/data/library-documents/NCCAP TechDoc.pdf

[79] Countries by Alphabetical Order. http://www.internetworldstats.com/list2.htm For a plan of a specific country type in google search "Climate Action Plan for the country of interest".

[80] The Whitehouse Offfice (USA) (2014) Climate Action Plan-Strategy to Cut Methane Emissions. https:/www.whitehouse.gov/the-press-office/2014/03/28/fact-sheet-climate-action-plan-strategy-cut-methane-emission $\underline{\mathrm{S}}$

[81] India (2008) India's Natiuonal Action Plan on Climatre Change. http://www.c2es.org/international/key-country-policies/india/climate-plan-summary

[82] National Development and Reform Commission of People's Republic of China (2007) China's National Climate Change Programme. http://en.ndrc.gov.cn/newsrelease/200706/P020070604561191006823.pdf

[83] European Commissiion (2014) 2030 Framework for Climate and Energy Policies. http://ec.europa.eu/clima/policies/2030/index_en.htm

[84] Grogan, D.S., Zhang, F., Prusevich, A., Lammers, R.B., Wisser, D., Glidden, S., Li, C. and Frolking, S. (2015) Quantifying the Link between Crop Production and Mined Groundwater Irrigation in China. Science of the Total Environment, 511, 161-175. http://www.ncbi.nlm.nih.gov/pubmed/25544335 https://web.stanford.edu/group/emf-research/docs/CCIIA/2014/Frolking additional.pdf

[85] Tai, A.P.K., Val Martin, M. and Heald, C.L. (2014) Threat to Future Global Food Security from Climate Change and Ozone Air Pollution. Nature Climate Change, 4, 817-821. http://www.nature.com/nclimate/journal/v4/n9/full/nclimate2317.html

[86] Pakistan Meteriology Division. Bibliography of Research Publications. Climate Dynamics. http://www.pmd.gov.pk/rnd/rndweb/rnd_new/publication.php

[87] List of Publications to Study Crop Yields/Loss in China to under Climate Change Scenerios (2014) https://www.apsim.info/Products/Publications.aspx

[88] Agricutural Meteriology Division (India). http://www.imdagrimet.gov.in/

[89] United States Agency for International Development (USAID) (2015) Proceedings of Workshop on Improving of Climate Services for Farmers in Africa \& South Asia (ICSFAFA). http://www.imdagrimet.gov.in/sites/default/files/Final\%20\%20Proceeding\%20of $\% 20$ Workshop $\% 202-3 \% 20$ February $\% 202015$ 0.pdf

[90] National Center for Environmental Information (NOAA) (2015) U.S. Climate Divisions. Climate at Glance. http://www.ncdc.noaa.gov/monitoring-references/maps/us-climate-divisions.php

[91] Kan, Y., Ma, X. and Khan, S. (2014) Predicting Climate Change Impacts on Maize Crop Productivity in the Loess Plateau. Irrigation and Drainage, 63, 394-404. http://onlinelibrary.wiley.com/doi/10.1002/ird.1799/abstract http://dx.doi.org/10.1002/ird.1799

[92] Tyagy, A.C. (2015) Aligning the Role of ICID in the Changing Development Paradigm. Irrigation and Drainage, 64, 152-153. http://onlinelibrary.wiley.com/doi/10.1002/ird.1923/abstract http://dx.doi.org/10.1002/ird.1923

[93] Yang, Z.W. (2012) The Right to Carbon Emission: A New Right to Development. American Journal of Climate Change, 1, 108-116. http://dx.doi.org/10.4236/ajcc.2012.12009

[94] De Wrachien, D. (2003) Paddy and Water Environment: Facilitation. Information Exchange and Identifying Future R \& D Needs. Paddy and Water Environment, 1, 3-5.

[95] Fears, D. (2015) A “Megadrought” Will Grip U.S. in the Coming Decades, NASA Researchers Say. Healh \& Science. 
http://www.washingtonpost.com/national/health-science/todays-drought-in-the-west-is-nothing-compared-to-What-ma y-be-coming/2015/02/12/0041646a-b2d9-11e4-854b-a38d13486ba1_story.html

[96] Cook, B. (2015) A "Megadrought" Will Grip U.S. in the Coming Decades, NASA Researchers Say. https://www.youtube.com/watch?v=8p9oJWg2FSI

[97] Francis, P. (2015) In Sweeping Encyclical, Calls for Swift Action on Climate Change. The New York Times, 18 June 2015.

http://www.nytimes.com/2015/06/19/world/europe/pope-francis-in-sweeping-encyclical-calls-for-swift-action-on-clim ate-change.html? $\mathrm{r}=0$

[98] Redford, R. (2015) Interview: "Climate Change Is in Everybody's Backyard”. United Nations Headquarters, New York.

[99] Mann, M. (2014) The Hockey Stick and the Climate Wars. https://www.youtube.com/watch?v=OZ7dPyxr98M

[100] UN News Center (2013) World Population Projected to Reach 9.6 Billion by 2050_UN Report. http://www.un.org/apps/news/story.asp?NewsID=45165\#.VaevevlViko

[101] UN News Center (2015) ADDIS: "Historic" Agreement Reached on Financing for New UN Sustainable Development Agenda. http://www.un.org/apps/news/story.asp?NewsID=51433\#.VaenuPIViko 